\title{
THE ISOLATED CONTRACT AS A BASIS OF JURISDICTION OVER NON-RESIDENTS
}

Single, isolated acts have generally been held an insufficient basis for jurisdiction of a state court over a non-resident. ${ }^{1}$ But where a cause of action, either in tort or in contract, arises from such an act, jurisdiction may be conferred by state statute. ${ }^{2}$ Most statutes of this type are limited to certain specialized fields-e.g., the use of highways, the sale of insurance, or the maintenance of real property. A few other statutes embrace any contract or act within the state which creates liability. ${ }^{3}$ All such legislation, whether limited or general in scope, raises the question of whether extension of jurisdiction based on isolated acts violates the due process clause of the Fourteenth Amendment. Although application of these statutes generally has been limited to tort actions, a recent Maryland case ${ }^{4}$ has sustained jurisdiction based on a purchase-and-sale contract. This case represents the furthest advance which the courts have made in extending jurisdiction over isolated acts.

This comment will consider whether the case can be reconciled with the recognized principles for upholding jurisdiction over the activities of non-residents. Traditional interpretations of due process and the practical policies which have influenced the recent trend toward less rigid jurisdictional requirements will be discussed.

\section{I}

In the Maryland case, Compania de Astral, S. A. v. Boston Metals Company, ${ }^{5}$ a local firm brought suit against a Panamanian corporation for breach of a contract to purchase three vessels which the defendant had refused to take after the imposition of onerous conditions by the United States Maritime Commission. Negotiations began in Maryland, but substantial agreement over terms was reached after further meetings in New York. Copies of the contract were signed simultaneously in Panama and Maryland, and defendant, in accordance with the terms, then deposited an escrow fund in a Baltimore bank. The contract allowed Astral to accept or reject the vessels after inspection in Maryland. Inspection was made, and defendant then sent its acceptance by mail from New Orleans to plaintiff's office.

The court held that the contract was made in Maryland; defendant therefore

(1)E.g., Begole Aircraft Supplies, Inc. v. Pacific Airmotive Corp., 121 Colo. 88, 212 P. 2d 866 (1949). Consult The Growth of the International Shoe Doctrine, 16 U. of Chi. L. Rev. $523,529-30$ (1949).

2 E.g., Md. Code Ann. (Flack, 1951) Art. 23, $\S 88$ (d), one of the earliest statutes of this type. Consult Reiblich, Jurisdiction of Maryland Courts over Foreign Corporations under the Act of 1937, 3 Md. L. Rev. 35 (1938).

${ }^{3}$ For a recent and comprehensive coverage, consult the Proposed Amendments to the Illinois Civil Practice Act \$17, Comment (September draft, 1954).

4 Compania de Astral, S.A. v. Boston Metals Co., - Md. -, 107 A. 2d 357 (1954). But cf. Edgewater Realty Co. v. Tennessee Coal, Iron \& R. Co., 49 F. Supp. 807, 816 (D. Md., 1943).

5-Md. -, 107 A. 2d 357 (1954). 
was amenable to suit under a state statute which conferred jurisdiction in actions arising out of contracts completed in the state. ${ }^{6}$ The opinion intimated that the mailing of an acceptance in Maryland alone would be inadequate to meet due-process requirements, even though the statute requires no additional contacts. Although the actions of the defendant constituted a single transaction within the state, they added up to considerable contact with the state. Moreover, reliance upon state laws was involved since the contract provided that in its construction and interpretation substantive Maryland law would control. ${ }^{7}$ The court recognized that the "single transaction" did not amount to "doing business" within the state, ${ }^{8}$ and therefore the "presence" of the defendant corporation had not been established. ${ }^{9}$ Instead, the court, in sustaining jurisdiction, relied in part on the doctrine announced in International Shoe Company v. Washington:

[D]ue process requires only that in order to subject a defendant to a judgment in personam, if he be not present within the territory of the forum, he have certain minimum contacts with it such that the maintenance of the suit does not offend "traditional notions" of fair play and substantial justice."10

While this oft-quoted statement of the test invoked in the International Shoe case does not on its face exclude the isolated-act cases, its precedent value is limited to situations of continuous activity by a corporation. The case involved a suit to recover unemployment compensation taxes against a corporation which had engaged in extensive solicitation of business within the state. The activities, which continued until the time of suit, were neither irregular nor casual." The court in the Astral case recognized that the International Shoe case

B "Every foreign corporation shall be subject to suit in this State by a resident of this State or by a person having a usual place of business in this State on any cause of action arising out of a contract made within this State or liability incurred for acts done within this State, whether or not such foreign corporation is doing or has done business in this State." Md. Code Ann. (Flack, 1951) Art. 23, $\S 88$ (d). The court had difficulty in holding that the contract had been completed within the state, the final acceptance having been mailed from without. In regard to this limitation on the jurisdiction conferred by the statute, see Ericksson v. Cartan Travel Bureau, Inc., 109 F. Supp. 315 (D. Md., 1953); Cole v. Randall Park Holding Co., 201 Md. 616, 95 A. 2d 273 (1953); Park Beverage Co. v. Goebel Brewing Co., 197 Md. 369, 79 A. 2d 157 (1951).

${ }^{7}$ Maryland's corporation act also so provides. Md. Code Ann. (Flack, 1951) Art. 23, § 85.

${ }^{8}$ Md. Code Ann. (Flack, 1951) Art. 23, \$ 84(b)(6).

"The terms "doing business" and "presence" represent successive steps in establishing jurisdiction over a corportation. Activities of the corporation may warrant the conclusion that it is "doing business"; once this conclusion is reached, the court then determines whether the business is conducted "in such manner and to such extent as to warrant the inference that it was present there." Rosenberg Brothers \& Co. v. Curtis Brown Co., 260 U.S. 516, 517 (1923); People's Tobacco Co. v. American Tobacco Co., 246 U.S. 79 (1918). That the terms are not necessarily synonymous is brought out in Kilpatrick v. Texas \& P. Ry. Co., 166 F. 2d 788 (C.A. 2d, 1948), cert. denied 335 U.S. 814 (1948).

10326 U.S. 310,316 (1945).

11 The leading case of Rosenberg Brothers v. Curtis Brown Co., 260 U.S. 516 (1923), held that sporadic visits by a corporate officer for the purpose of executing purchase-and-sale contracts were insufficient to confer jurisdiction over the corporation even though the cause of action arose within the state. This decision has been modified by International Shoe Co. v. 
involved continuous business activity within the state but noted that the decision in that case was not based on the jurisdictional requirement of "doing business."

Prior to International Shoe continuous solicitation was not regarded as "doing business."12 The Supreme Court, in order to uphold jurisdiction, was thus faced with the alternatives of expanding the "doing-business" concept or substituting another criterion. In choosing the latter it recognized that a lesser amount of activity might sustain jurisdiction if the cause of action arose out of the activity $^{13}$ and an estimate of the relative inconveniences to the parties indicated that the defendant might reasonably be subjected to suit.14

In one respect the International Shoe case is markedly different from the Astral case. Although the activity involved in International Shoe was less than would amount to "doing business," the acts continued until the initiation of the suit. In the Astral case the making of the contract constituted the defendant's only activity within the state. The Astral court failed to recognize that the International Shoe case was concerned with jurisdictional "presence" in a situation involving activity continuing up to the time of suit, ${ }^{15}$ and was not con-

Washington, 326 U.S. 310 (1945), only to the extent that if a corporation's continuous activity does not constitute "doing business," it may nevertheless be material that the cause of action arises within the state. The Rosenberg case has continued as authority in cases where acts within the state have not been continuous. Latimer v. S/A Industrias Reunidas F. Matarazzo, 175 F. 2d 184 (C.A. 2d, 1949) (action in contract brought by non-resident); Flanagan v. Acme Scaffold Co., 277 App. Div. 988, 100 N.Y.S. 2d 15 (2d Dep't, 1950). Compare McWhorter v. Anchor Serum Co., 72 F. Supp. 437 (W.D. Ark., 1947), with Gillioz v. Kincannon, 213 Ark. 1010, 214 S.W. 2d 212 (1948).

12 E.g., Green v. Chicago, B. \& Q. Ry. Co., 205 U.S. 530 (1907) (action for personal injuries sustained outside of the state in which the defendant solicited business).

${ }^{13} \mathrm{It}$ was later held that where the corporation is actually doing business, jurisdiction will be conferred in causes of action arising outside the state. Perkins v. Benguet Consolidated Mining Co., 342 U.S. 437 (1952). Accord: Tauza v. Susquehanna Coal Co., 220 N.X. 259, 115 N.E. 915 (1917).

${ }^{14}$ Conflict of opinion exists as to the effect of the International Shoe case on the rule that solicitation alone does not constitute "doing business." According to Judge Learned Hand in Kilpatrick v. Texas \& P. Ry. Co., 166 F. 2d 788 (C.A. 2d, 1948), cert. denied 335 U.S. 814 (1948), the doctrine was not overruled. Instead, the Supreme Court, finding that solicitation in the International Shoe case did not constitute "doing business," based its decision upon the "presence" of the corporation, determined by activities plus an estimate of conveniences to the parties. Contra: Jeter v. Austin Trailer Equipment Co., 122 Cal. App. 2d 376, 265 P. 2d 130 (1953). Some courts, however, have interpreted the International Shoe case as holding that the "doing-business" concept is satisfied by solicitation plus other activities. Lutz v. Foster \& Kester Co., 367 Pa. 125, 79 A. 2d 222 (1951); Law v. Atlantic Coast Line R. Co., 367 Pa. 170, 79 A. 2d 252 (1951); Fiorella v. Baltimore \& Ohio R. Co., 89 F. Supp. 850 (E.D. Pa., 1950); Marlow v. Hinman Milking Machine Co., 7 F.R.D. 751 (D. Minn., 1947); New v. Robinson-Houchin Optical Co., 357 Pa. 47, 53 A. 2d 79 (1947). Compare Frene v. Louisville Cement Co., 134 F. 2d 511 (App. D.C., 1943) (solicitation plus a very little more), and especially the concurring opinion of Judge Edgerton, at 518, in distinguishing Green v. Chicago, B. \& Q. Ry. Co., 205 U.S. 530 (1907).

${ }^{15}$ For an analysis of the "presence" doctrine, consult Hutchinson v. Chase \& Gilbert, Inc., 45 F. 2d 139 (C.A. 2d, 1930), and Kilpatrick v. Texas \& P. Ry. Co., 166 F. 2 d 788 (C.A. 2d, 1948). 
cerned directly with the quantity or quality of acts at the time the cause of action arose.

The importance of this factual distinction is made doubtful by cases in which the corporation had ceased doing business in the forum state but was nonetheless subjected to suit on obligations arising out of the business activity. Several early cases, regarding the obligations existing after the corporation left the state as a continuation of "doing business,"16 concluded that corporate "presence" existed at the time of suit. Later decisions, without reference to the notion that the obligations amounted to "doing business," held that the continuing obligations were adequate to sustain jurisdiction. ${ }^{17}$ At least one case has applied the doctrine of International Shoe to a situation where other activity had ceased but obligations remained. ${ }^{18}$ Thus, if the distinction between activity at the time the cause of action arose and at the time of suit is ignored, International Shoe could be regarded as upholding jurisdiction based on a single isolated act. This result is readily achieved since the liability which the single act created could be regarded as the continuing obligation which these cases have emphasized.

If the above reasoning is regarded as unsatisfactory, the underlying principles of the International Shoe case may nonetheless be invoked where the cause of action arises out of activity within the state and it is not unduly inconvenient for the defendant to be sued there. This basic concept of fairness is derived from the Court's conviction that a non-resident corporation which enjoys the privileges extended by a state must assume corresponding responsibilities. Or, as quoted by the Astral court from the International Shoe opinion:

[T]o the extent that a corporation exercises the privilege of conducting activities within a state, it enjoys the benefits and protection of the laws of that state. The exercise of that privilege may give rise to obligations; and, so far as those obligations arise out of or are connected with the activities within the state, a procedure which requires the corporation to respond to a suit brought to enforce them can, in most instances, hardly be said to be undue..$^{9}$

\section{II}

But more directly in point than the principles expressed in the International Shoe case is a series of cases factually more similar to the Astral case involving single acts, in fields of highly regulated activity, which give rise to tort liability or isolated contract obligations.

${ }^{16}$ Commercial Mutual Accident Co. v. Davis, 213 U.S. 245 (1909); Mutual Reserve Fund Life Ass'n v. Phelps, 190 U.S. 147 (1903); Connecticut Mutual Life Ins. Co. v. Spratley, 172 U.S. 602 (1899).

${ }^{17}$ Edgewater Realty Co. v. Tennessee Coal, Iron \& R. Co., 49 F. Supp. 807 (D. Md. 1943); American Railway Express Co. v. Royster Guano Co., 273 U.S. 274 (1927).

${ }^{18}$ Parmalee v. Iowa State Traveling Men's Ass'n, 206 F. 2d 518, 522 (C.A. 5th, 1953) (action on insurance policy); cf. Davis-Wood Lumber Co. v. Ladner, 210 Miss. 863, 50 So. 2d 615 (1951).

19 - Md. - , - 107 A. 2d 357, 367 (1954), quoting from International Shoe Co. v. Washington, 326 U.S. 310, 319 (1945). 
Cases which have advanced the breakdown of territorial limitations on jurisdiction ${ }^{20}$ have for the most part involved isolated torts rather than contracts. In one of the furthest extensions of jurisdiction over a foreign corporation, the Vermont Supreme Court recently allowed an action for damages by a Vermont resident against a Massachusetts corporation for negligence in repairing a roof on the plaintiff's house. ${ }^{21}$ The court observed

a dual trend in jurisdictional decisions: in defining the court with jurisdiction, a trend from the court with immediate power over the defendant to the court where both parties may most conveniently settle their dispute; and in defining due process of law, a trend from emphasis on the territorial limitations of courts to emphasis on providing notice and opportunity to be heard.22

The opinion emphasized the practical considerations of notice and relative inconvenience to the parties rather than the "presence"23 of the defendant or the existence of any state regulatory policy over the type of activity involved.

Jurisdiction based upon isolated torts was initially upheld by the Supreme Court in Hess v. Pawloski, ${ }^{24}$ a case involving an action for personal injuries against a non-resident motorist. Prior decisions had established (1) that a state might require a non-resident to obtain a license before driving on state highways, ${ }^{25}$ and (2) that issuance of the license might be conditioned upon the motorist's express consent to substituted service of process on a state official in actions arising out of highway accidents. ${ }^{26}$ With these precedents at hand, the Court in the Hess case had little difficulty in upholding the constitutionality of a state statute which provided that if a non-resident motorist used the state highways his consent to substituted service of process would be implied. Although the Court used the familiar pattern of the consent doctrine, ${ }^{27}$ it found the exten-

${ }^{20}$ Consult Pennoyer v. Neff, 95 U.S. 714 (1877), for a discussion of territorial limitations on jurisdiction.

${ }^{21}$ Smyth v. Twin State Improvement Corp., 116 Vt. 569, 80 A. 2d 664 (1951), noted in State Jurisdiction over Foreign Corporations, 34 B.U.I. Rev. 185 (1954). While the nature of the agreement between the parties was unknown, it has been contended that jurisdiction would preferably have been based upon contract. However, it is recognized that earlier authority was more easily distinguished by basing the action on a tort rather than a contract.

2 Smyth v. Twin State Improvement Corp., 116 Vt. 569, 575, 80 A. 2d 664, 668 (1951).

${ }^{23}$ While the Vermont jurisdictional statute equates a tort or a contract within the state to "doing business," Vt. Rev. Stat. (1947) c. $47, \S 1562$, the court chose to refer directly to isolated acts as a basis of jurisdiction. Literal interpretations of the Vermont statute have suggested that if it is found on the merits that no tort has been committed, jurisdiction will have been lacking and the judgment will not be res judicata. Consult, e.g., 26 St. John's L. Rev. 166 (1951), noting Smyth v. Twin State Improvement Corp., 116 Vt. 569, 80 A. 2d 664 (1951).

24274 U.S. 352 (1927). Highway accidents can also serve as a basis of jurisdiction over corporations. E.g., Poti v. New England Road Machinery Co., 83 N.H. 238, 140 Atl. 587 (1928).

25 Hendrick v. Maryland, 235 U.S. 610 (1914).

${ }^{26}$ Kane v. New Jersey, 242 U.S. 160 (1916).

${ }^{27}$ Early cases sustaining jurisdiction over corporations held that by doing business within the state, they are deemed to have consented to suit. E.g., Lafayette Ins. Co. v. French, 18 
sion of jurisdiction to be justified in the light of the dangerous nature of automobiles and the inherent fairness of requiring the defendant to appear in court at the place where the accident occurred. ${ }^{28}$ Procedures reasonably calculated to give actual notice to the defendant, which the Court found had been provided for in the Hess case, later became firmly established as a criterion for determining the validity of such service. ${ }^{29}$

The particular facts and the background of extensive state regulation of motor vehicles which contributed to the result in the Hess case have often been employed to limit the use of substituted service of process as applied to isolated acts. Under this limitation, jurisdiction may not be expanded when the activity involved in the litigation is not the subject of special regulation under the state police power. ${ }^{30}$ In Johns v. Bay State Abrasive Products Company, ${ }_{2}^{31}$ a case concerning the same Maryland statute ${ }^{32}$ which was applied in the Astral case, the court respected this limitation in requiring more continuous activity within the state where the particular activity was not highly regulated. The Maryland court in the Astral case and the Vermont court in Smyth v. Twin State Improvement Corporation ${ }^{33}$ have thus departed from these earlier cases by abandoning this limitation on the type of sporadic or isolated acts which can support a finding of jurisdiction.

It is reasonably clear that the Maryland and Vermont decisions do not represent the prevailing view concerning jurisdiction based on isolated or occasional acts within a state. Several cases arising under broad jurisdictional statutes illustrate the general emphasis on regulation of activities dangerous to life or property. ${ }^{34}$ In two personal-injury cases arising in Mississippi, both construction work on a levee ${ }^{35}$ and work in a lumber yard ${ }^{36}$ were found to be "fraught with danger." The court noted, moreover, that the activity was subject to the power of the state to require coverage by workmen's compensation insurance

How. (U.S.) 404 (1856). For criticism of this fiction, consult Goodrich, Conflict of Laws $\$ 76$ (3d ed., 1949).

${ }^{28}$ Consult, e.g., Scott, Hess and Pawloski Carry On, 64 Harv. L. Rev. 98, 100 (1950). More recently, the Supreme Court refused to apply the consent doctrine to imply a waiver of federal venue privileges by a non-resident motorist. Olberding v. Illinois Central R. Co., 346 U.S. 338 (1953).

${ }^{29}$ Wuchter v. Pizzutti, 276 U.S. 13 (1928) (jurisdiction invalid when conferred by statute which did not require that notice of service of process be sent to defendant).

${ }^{30}$ Rest., Conflicts $\$ 85$, Comment $\mathrm{c}$ (1934) (acts of a dangerous nature which states might constitutionally make illegal unless the non-resident consents to suit). The more recent Restatement of Judgments is less stringent, but the rule adopted is limited to acts of a dangerous nature. Rest., Judgments $\$ 23$ (1942).

3189 F. Supp. 654 (D. Md., 1950), noted in 64 Harv. L. Rev. 500 (1951).

22 Md. Code Ann. (Flack, 1951) Art. 23, §88(d).

33116 Vt. 569, 80 A. 2d 664 (1951).

${ }^{34}$ Miss. Code Ann. (1942) c. 3, § 1437. Consult Ark. Stat. Ann. (1947) tit. 27, §340.

${ }^{35}$ Sugg v. Hendrix, 142 F. 2d 740 (C.A. 5th, 1944).

${ }^{36}$ Davis v. Nugent, 90 F. Supp. 522 (S.D. Miss., 1950). 
although the legislature had not acted. This emphasis upon the state regulatory power illustrates the nature of the limitation which the courts have imposed under modern statutes conferring jurisdiction. The cases also suggest that if the state has the power to regulate the activity involved it is immaterial that the power has not been exercised. Stating the limitation in this way actually means that there is no limitation at all since the state is empowered to regulate every kind of activity which goes on within its borders subject only to constitutional restrictions. The courts, however, may have had in mind only regulated activities or occupations which, when conducted by non-residents within the state, would leave its citizens at a peculiar disadvantage. Such activities might include the sale of securities ${ }^{37}$ or the offering of professional services of a highly specialized or technical nature ${ }^{38}$-activities in which the purchaser must place considerable trust in the seller.

Some cases which have rationalized the assumption of jurisdiction on the power of the state to regulate the particular activity have suggested that jurisdiction might be upheld on a broader ground. The language in the earliest Mississippi case involving construction work has been frequently repeated:

The thought is not shocking that one who comes into a state for the purpose of conducting his business in that state should be made amenable to the courts and laws of the state and answerable to its citizens for damages sustained by them which were the result of the business transacted in the state..$^{39}$

Such reasoning has been applied directly in upholding a statute conferring jurisdiction over a non-resident owner or user of real property within the state in an action for injuries sustained on the property. ${ }^{40}$ And, recently, a federal district court, finding no valid distinction between non-resident motorists and non-resident vessel owners, held that

The state's right and duty to provide protection for persons and property on its navigable waters are no less important than its right and duty to provide like protection for persons on its highways. ${ }^{41}$

Contracts, as well as torts, have been made the basis of jurisdiction where the contract was made in the course of activity likely to prove harmful to state residents unless the activity were highly regulated. A case coming within this hybrid classification is a contract action arising out of activity ordinarily giving rise only to liability in tort. In Illinois, for example, jurisdiction was assumed

${ }^{37}$ Doherty \& Co. v. Goodman, 294 U.S. 623 (1935).

${ }^{38}$ Condon v. Snipes, 205 Miss. 306, 38 So. 2d 752 (1949) (insect extermination); Ritholz v.. Dodge, 210 Ark. 404, 196 S.W. 2d 479 (1946) (optometry). Consult Acts of 1947 General Assembly, 1 Ark. L. Rev. 201, 202 (1947).

${ }^{39}$ Sugg v. Hendrix, 142 F. 2d 740, 743 (C.A. 5th, 1944).

10 Dubin v. Philadelphia, 34 Pa. Dist. \& Co. 61 (1938), applying Pa. L. (1937) 2747, § 1, as amended, Pa. Stat. Ann. (Purdon, 1953) tit. 12, §331.

« Tardiff v. Bank Line, Ltd., 127 F. Supp. 945 (E.D. La., 1954). 
over an action in contract for indemnification on the basis of the state nonresident motorist statute. ${ }^{42}$ The defendant, a non-resident, had leased to the plaintiff a tractor-trailer to be operated by the defendant's employee. The plaintiff, as the borrowing employer, had been held liable to third parties for injuries caused by the negligence of the truck driver, and he was then allowed to sue the defendant in the Illinois courts for indemnification. Other cases arising under the motorist statutes have upheld jurisdiction over actions involving claims for workmen's compensation ${ }^{43}$ and contribution among joint tortfeasors" upon an "implied-contract" theory.

Where the activity conducted by non-residents involves the negotiation of contracts, state legislatures are inclined to confer and courts likely to sustain jurisdiction if the state residents, because of the nature of the business, are at a peculiar disadvantage in bargaining position. As early as 1856, in Lafayette Insurance Company v. French, ${ }^{45}$ the Supreme Court held that a state might reasonably secure to its residents a remedy in the domestic forum upon contracts of insurance if the policy was issued and was to be performed within the state. At that time, however, the Court placed strong emphasis upon the power of the state to exclude foreign corporations unless they consented to the jurisdiction by compliance with local regulation. More recently, the Supreme Court has upheld state legislation affording special extra-territorial protection to resident purchasers of insurance. ${ }^{46}$ Moreover, the states have full authority under the $\mathrm{McCarran} \mathrm{Act}^{47}$ to regulate interstate commerce in the field of insurance.

While the state's power to regulate may not be the measure of its power to extend jurisdiction in actions arising out of insurance policies, ${ }^{48}$ the cases establishing a state's vested interest in protecting its citizens in the field of insurance point toward the reasonableness of the assumption of jurisdiction. In Travelers

42 Dart Transit Co. v. Wiggins, 1 IIl. App. 2d 126, 117 N.E. 2 d 314 (1953).

${ }^{43}$ Maddry v. Moore Brothers Lumber Co., 195 La. 979, 197 So. 651 (1940).

${ }^{41}$ Southeastern Greyhound Lines v. Myers, 288 Ky. 337, 156 S.W. 2d 161 (1941). Accord: McKay v. Citizens Rapid Transit Co., 190 Va. 851, 59 S.E. 2d 121 (1950).

4518 How. (U.S.) 404 (1856).

${ }^{46}$ Osborn v. Ozlin, 310 U.S. 53 (1940) (statute requiring resident agents of insurance companies to receive at least one-half of commissions paid on insurance policies in order to encourage the practice of agents in advising policyholders on how to minimize risks); Hoopeston Canning Co. v. Cullen, 318 U.S. 313 (1943) (statute requiring licenses of foreign reciprocal insurance companies executing all contracts out of state); cf. La Tourette v. McMlaster, 248 U.S. 465 (1919) (brokers required to be residents of state for two years, the activities of insurance brokers being under state control).

4759 Stat. 33, 34 (1945), 15 U.S.C.A. $\$ \S 1011-15$ (1948), held constitutional in Prudential Ins. Co. v. Benjamin, 328 U.S. 408 (1946).

${ }^{48}$ Jeter v. Austin Trailer Equipment Co., 122 Cal. App. 2d 376, 265 P. 2d 130 (1954) (jurisdiction for service of process, while lacking power to regulate or tax); Provident Savings Life Assurance Co. v. Kentucky, 239 U.S. 103 (1915) (power to confer jurisdiction greater than to tax); Travelers Health Ass'n v. Virginia, 339 U.S. 643 (1950) (concurring opinion of Mr. Justice Douglas, at 653). 
Health Association v. Virginia, ${ }^{49}$ the Supreme Court, recognizing this doctrine and combining it with that of the International Shoe case, held that a state court had jurisdiction to issue a cease-and-desist order against a foreign insurance company which solicited business only through its policyholders. The Court was apparently willing to allow an extension of judicial jurisdiction to enforce insurance legislation. The reasoning of the case has since been applied by the Court of Appeals for the Fifth Circuit in a decision allowing an action against a company which conducted all of its business within the state by mail. ${ }^{50}$

In the case of Doherty \& Co. v. Goodman, ${ }^{51}$ where the regulated activity was that of selling securities, jurisdiction acquired over a non-resident individual through service of process upon his resident agent was sustained. The Supreme Court, relying heavily upon the language in a state decision, upheld jurisdiction upon the broad ground that

A non-resident who gets all the benefit of the protection of the laws of this state with regard to the office or agency and the business so transacted ought to be amenable to the laws of the state as to transactions growing out of such business upon the same basis and conditions as govern residents of this state. ${ }^{52}$

Thus, the emphasis was not upon the special regulation of the securities business, though the court did rely in part upon this factor in distinguishing the case of Flexner v. Farson, ${ }^{53}$ which had denied jurisdiction under similar circumstances. The court in the Astral case refused to recognize this limitation based on the character of the business involved and instead regarded the Doherty case as

49339 U.S. 643 (1950). Accord: Ace Grain Co. v. American Eagle Fire Ins. Co. of New York, 95 F. Supp. 784 (S.D. N.Y., 1951).

${ }^{\text {so }}$ Parmalee v. Towa State Traveling Men's Ass'n, 206 F. $2 d 518$ (C.A. 5th, 1953). Contacts within the state were limited, and the other outstanding insurance policies were not emphasized by the court. The importance given to regulating activities of foreign insurers within the forum is indicated by the next opinion of the court in which jurisdiction was denied in an action by the same plaintiff upon a policy mailed into another state. Parmalee v. Commercial Travelers Mut. Acc. Ass'n of America, 206 F. 2d 523 (C.A. 5th, 1953).

${ }^{51} 294$ U.S. 623 (1935).

52 Ibid., at 627. The Court quoted from Davidson v. Doherty \& Co., 214 Iowa 739, 743, 241 N.W. 700, 702 (1932), which had held constitutional an Iowa statute providing for service of process upon an agent or clerk in an office or agency maintained by a corporation, company, or individual in any county other than that in which the principal resides. Iowa Code (1931) c. $489, \S 11079$, as amended, Iowa Code (1954) c. 617, R.C.P. 56(f). Accord: Wein v. Crockett, 113 Utah 301, 195 P. 2d 222 (1948) (contract action against individual doing business); Stoner v. Higginson, $316 \mathrm{~Pa} .481,175$ Atl. 527 (1934) (partnership doing business); cf. Deutsch v. Hoge, 146 F. 2d 201 (C.A. 2d, 1944) and the dissenting opinion of Judge Learned Hand, at 203, who would have held that a series of contracts completed out of state constituted doing business.

53 248 U.S. 289 (1919). Flexner v. Farson was also distinguished upon the ground that the agency relationship had ceased before service of process. However, the case may be regarded as based upon the broader ground that, since a state cannot exclude a non-resident individual from doing business, neither can it subject him to jurisdiction in causes of action arising from such business. Consult Scott, Jurisdiction over Nonresident Motorists, 39 Harv. L. Rev. 563, 582 et seq. (1926). If this interpretation is adopted, the distinctions drawn in the Doherty case are immaterial, and Flexner v. Farson should be considered as overruled. 
rendering untenable the argument that a single contract could not be made the basis for jurisdiction (even though the defendant in Doherty had made more than one contract).

The narrower approach to the Doherty case which the Astral case disregarded was emphasized in a Mississippi case involving a contract for regulated personal services. ${ }^{54} \mathrm{~A}$ non-resident licensed by the state to engage in the business of insect extermination was held subject to the court's jurisdiction in an action for breach of contract brought by a resident. The court explicitly refused to pass upon the validity of the particular statute in cases where the defendant would not be subject to state regulation..$^{5}$

In all of these contract cases the defendants, in addition to the simple execution of the contract, had engaged in other activities within the state, and the courts in each case gave some attention to the quality or the quantity of these acts. Even in the Astral case, the court noted that the defendant had deposited an escrow fund and inspected the vessels while in Maryland, but these acts were regarded as amounting to only one transaction. Although this additional activity might be important in establishing the "presence" of a corporate defendant, it becomes immaterial when the defendant is an individual who is not physically within the state at the time of suit, since the "presence" fiction cannot, or at least has not, been applied to natural persons. ${ }^{56}$ Nevertheless, it appears that the courts have sought psychological comfort in stressing the activity surrounding the actual making of a contract. These courts would probably be unwilling to sustain jurisdiction if the contract had been concluded simply by an exchange of letters between residents of different states.

\section{III}

In determining whether requirements of due process have been met, the fact that the activity used as a basis for jurisdiction is regulated by the state should be relevant only insofar as the cause of action is one which is embraced within the state's protective policy. The requirement that a non-resident, particularly

st Condon v. Snipes, 205 Miss. 306, 38 So. 2d 752 (1949).

${ }_{55}$ Two years later, the Mississippi Supreme Court upheld jurisdiction in a contract action brought against a foreign corporation. The court labelled as artificial the distinction between jurisdiction founded upon doing business in a state which involves danger to life or property or state regulation and, on the other hand, contractual obligations arising out of such business. Davis-Wood Lumber Co. v. Ladner, 210 Miss. 863, 884, 50 So. 2d 615, 624 (1951). Consult Goodrich, Conflict of Laws $\$ 76$, at 216 (3d ed., 1949). However, the court gave a narrow interpretation to the state statute conferring jurisdiction over non-residents who do "any business or perform any character of work or service" within the state in actions arising out of such activity. Miss. Code Ann. (1942) c. 3, §1437. Compare Lee v. Memphis Publishing Co., 195 Miss. 264, 14 So. 2d 351 (1943) (jurisdiction denied over action in libel), and the dissenting opinion at 283 and 357 , observing the language of the statute and noting the possibility of hardship to a plaintiff who is forced to sue out of state.

${ }^{36}$ It is notable, though, that the activities which would establish the doing of business by an individual may be much the same as those which establish corporate "presence." Deutsch v. Hoge, 146 F. 2 d 201 (C.A. 2d, 1944). 
an individual, submit to service of process as a condition precedent to engaging in activities within a state might be considered an unreasonable burden on one's privilege of passing unimpeded through the several states. But, when notice of suit is fairly calculated to reach the defendant, the burden on him may not be unreasonable in view of the disadvantages to a resident who may be unable to seek redress for loss arising out of activity for which state protection to such residents has been found necessary. Statutes designed to insure safe driving are consistent in policy with legislation allowing a resident to recover in a state court for injuries caused by a non-resident motorist. Again, where local insurance beneficiaries are induced to purchase policies from non-resident companies which later default in their obligations, jurisdictional statutes are one facet of the necessary protection which a state should afford to its citizens. But where the activity is regulated, for example, to protect against fraud, and the action arises upon a bona fide contract which is not within the protective policy, the regulation of the activity does not make substituted service of process more reasonable.

On the other hand, even if no regulatory policy over the activity has been established, substituted service upon a non-resident is not necessarily unreasonable or less justified. Although particular activity might not be so potentially harmful as to stimulate state-wide regulation, the disadvantage in litigating out of state on a claim arising out of the activity is the same. For example, it might be equally inconvenient for a Virginia resident to litigate a claim in Nebraska whether arising out of a purchase-and-sale contract or an insurance policy; ${ }^{57}$ and a factory employee injured in Maryland would be equally inconvenienced whether recovering in Texas for injuries resulting from a defective machine tool or from an automobile accident. ${ }^{58}$ Similarly, the burden on the defendant, if he has notice of suit, will be no greater regardless of the kind of action to which his activities give rise. Thus, while the principle of special legislative protection may have originally revealed the need for extending jurisdiction, the limitations inherent in the principle are no longer necessary. Instead, the courts might better concern themselves with effective notice, opportunity to be heard, and the relative inconveniences to the parties in litigating at a particular time and place.

Certain considerations of convenience and reasonableness common to all actions in contract should be observed in determining the most appropriate forum. With regard to particular types of contracts, such as insurance policies or employment contracts, one or more of these considerations may be of such importance as to be determinative of where the action may be brought. Where the other factors are evenly balanced, the applicable state law may be determinative ${ }^{59} \mathrm{It}$ is, of course, desirable that the governing law be applied by the

57 Consult Travelers Health Ass'n v. Virginia, 339 U.S. 643 (1950).

${ }^{68}$ Consult Johns v. Bay State Abrasive Products Co., 89 F. Supp. 654 (D. Md., 1950).

${ }^{69}$ Consult Blair, The Doctrine of Forum Non Conveniens in Anglo-American Law, 29 Col. L. Rev. 1, 30-32 (1929). 
courts which are most familiar with it. Thus, the action might be allowed in that state in which the contract was made or is to be performed since the courts might then apply their own law. Furthermore, assuming that the parties have contracted with reference to the law of a particular state, it might be important for the courts of that state to settle the dispute inasmuch as other states might refuse to enforce the contract, either in whole or in part, as repugnant to public policy. ${ }^{60}$

Some of the peculiarities existing in the non-resident motorist situation which have led the courts to sustain jurisdiction do not exist in ordinary contract cases. Witnesses are often not so important in contract actions, and they may reside in the defendant's state or in the plaintiff's. ${ }^{61}$ Moreover, the advantage of holding trial near the scene of the accident has no counterpart in simple contract actions. Finally, the more inarticulate notions of the courts concerning non-resident motorist cases-the ability of the non-resident to gain immunity by leaving the state and the serious risks involved in auto transportation-are not present in ordinary contract cases.

Where the contract is of a specialized type, certain generalizations may be made which tend to justify jurisdiction over non-residents. For example, where insurance contracts are involved, it may perhaps be assumed that the company is prepared to handle claims in every state where policies have been sold, ${ }^{62}$ while the policyholder can, with convenience and relatively small expense, litigate only in his own state. Or, where the non-resident's activity within the state is accorded special protection by means of legislative regulation, it may be assumed that he should, in all fairness, bear whatever responsibilities such regulation may impose; in other words, submission to jurisdiction in return for protection. It may be added that the same notion of fairness applies regardless of the action involved and may, in part, explain the fact that the courts have emphasized continuous or substantial activity in the state rather than the inconvenience of the parties.

The Astral case was peculiarly appropriate for the application of the Maryland jurisdictional statute. Concededly, the case sets the pace for broader extensions of jurisdiction, disregarding older concepts of corporate consent and presence, police power, and unusual danger. Yet, the defendant in the case received actual notice of the action brought against him and was given the opportunity to defend on the merits. The assumption of jurisdiction over the action appeared quite reasonable in the light of the defendant's acts in addition to the making of an ordinary purchase-and-sale contract. While litigating in Panama might have been extremely inconvenient to the plaintiff, it was not equally in-

${ }^{\circ 0}$ Consult, generally, Goodrich, Conflict of Laws § 106 (3d ed., 1949).

${ }^{61}$ But note that the witnesses to the transaction in the Astral case were apparently important. All, including counsel, auctioneer, shipbroker, and an official of the United States Maritime Commission, were located relatively near Baltimore. Brief for appellee at 9, 13, n. *, Compania de Astral v. Boston Metals Co., — Md. -, 107 A. 2 d 357 (1954).

62 E.g., Commercial Mutual Accident Co. v. Davis, 213 U.S. 245 (1909) (service of process on doctor sent into state to examine body and settle claim). 
convenient for the defendant to appear in Maryland. He was represented by an agent in the United States, and only documentary evidence was needed from Panama. The contract provided that Maryland law should govern its construction and that performance was subject to approval by several agencies of the United States government. Finally, it is worth noting that the defendant voluntarily agreed to perform the contract in Maryland, and he in fact carried out some of the obligations before breach.

The Maryland court expressly limited its decision to the facts before it. The mere mailing of an acceptance in Maryland would have been insufficient, in the court's view, to establish jurisdiction. The decision does not establish any certain criteria for the determination of jurisdiction over non-residents; yet, lack of certainty is not new in this field. Practical concern for notice, convenience and adequate chance to defend are more appropriate and no less certain than attempting to establish the "doing of business" and corporate presence.

\section{EFFECT OF 1404(a) TRANSFER ON FEDERAL JURISDICTION OVER FOREIGN CORPORATIONS}

International Shoe Co. v. Washington ${ }^{1}$ may be read as establishing two requirements for obtaining jurisdiction over a foreign corporation which has not consented to suit in the forum: (1) there must be physical activity within the state of more than incidental nature, and (2) it must not be grossly unfair to force the corporation to defend the suit in the forum. The second requirement necessitates "an estimate of the inconveniences" to the defendant, and is therefore closely related to Section 1404(a) of the Federal Judicial Code which provides that: "For the convenience of parties and witnesses, in the interest of justice, a district court may transfer any civil action to any other district or division where it might have been brought." "Judge Learned Hand has even gone so far as to state that the two issues are "certainly indistinguishable." $\mathrm{A}$ curious

${ }^{1} 326$ U.S. 310 (1945).

2 Ibid., at 317.

362 Stat. 937 (1948), as amended, 28 U.S.C.A. $\$ 1404$ (a) (1952).

4 Kilpatrick v. Texas \& P. Ry. Co., 166 F. 2d 788 (C.A. 2d, 1948). Judge Hand was speaking of the doctrine of forum non conveniens rather than of Section 1404(a). However, the considerations underlying both doctrines are identical. The reviser of the United States Code says that Section 1404(a) "was drafted in accordance with the doctrine of forum non conveniens." Reviser's note, 28 U.S.C.A. \$ 1404 (1950). This interpretation has been described by the Supreme Court as "obviously authoritative." United States v. National City Lines, 337 U.S. 78, 81 (1949). There have been some dicta to the contrary: see Jiffy Lubricator Co. v. Stewart-Warner Corp., 177 F. 2 d 360 (C.A. 4th, 1949); Headrick v. Atchison Topeka \& S.F. Ry. Co., 182 F. 2 d 305 (C.A. 10th, 1950); All States Freight v. Modarelli, 196 F. 2d 1010 (C.A. 3d, 1952), but these cases have been concerned with the difference between transfer and dismissal rather than with the considerations underlying the doctrines. For an extensive and comprehensive discussion of the relation between Section 1404(a) and the doctrine of forum non conveniens, consult Currie, Change of Venue and the Conflict of Laws, $22 \mathrm{U}$. of Chi. L. Rev. 405 (1955). 